\title{
The Advent of Competing Foreign Powers in the Geostrategic Horn of Africa: Analysis of Opportunity and Security Risk for Ethiopia
}

\author{
Gashaw Ayferam, Zelalem Muchie \\ Addis Ababa University, Addis Ababa, Ethiopia
}

This paper examines the opportunity and security implication of the advent of competing foreign powers in the geostrategic Horn of Africa for Ethiopia. Accordingly, the paper argues that since the advent of competing foreign powers in Horn of Africa is both an opportunity and security risk for Ethiopia, there is a need for a rational and assertive foreign policy aimed at utilizing the opportunity, minimizing the risk and countering neo-colonialism and "Clientelism". Methodologically, the study employed qualitative research methodology. Accordingly, the study used secondary source of data; collected from books, published journal articles, published and unpublished theses and dissertation, governmental and non-governmental organization reports and remarks, magazines and other internet sources. To substantiate the data, the paper also used primary data collected through key informant interviews. Given the data gathered are qualitative, the study employed qualitative data analysis techniques. The finding of the study shows that Horn of Africa has become "an athletic field" of foreign powers. It can be argued that the region has become "a military garrison": US, France, Germany, Italy, Japan, China and Saudi Arabia have already established their military base at Djibouti. Thus, the militarization of the Horn is both an opportunity as well as a risk for Ethiopia, a nucleus and landlocked country of the sub-region. It is an opportunity in areas of military, regional stability, accelerating factor of regional integration and economic worth. However, these opportunities are largely determined by the Ethiopia's diplomatic utmost effort and policy reorientation. Despite these opportunities, the rise of foreign powers in the Horn of Africa has a security risk: national security, economic, political and military. Therefore, Ethiopia needs a rational and assertive foreign policy to utilize the opportunities and at times to minimize the security risk. First, in domestic policy setting constitutionalism is highly needed which is imperative. Second, regionally, Ethiopia must stabilize and normalize its relation with Eritrea. Moreover, Ethiopia must strength its relation with all of its neighbors. Third, Ethiopia must maintain a good relation with foreign powers that already established a military base in Djibouti. In this regard, over-reliance on some foreign powers and neglecting others, becoming an instrument of foreign powers must be avoided. Rather Ethiopia must use a rational policy and at times must follow the foreign policy of Emperor Menelik "playing one foreign power over the other". Moreover, emphasis also should be given to the importance of collective security. Finally, Ethiopia and the region must work towards countering neo-colonialism and patron-client relations. Falling to adopt countering strategy may be quoted as "neo-colonialism and Clientelism" by invitation.

Keywords: Horn of Africa, geopolitics, diplomacy, foreign policy, clientelism

Gashaw Ayferam, Graduate Student, Department of Political Science and International Relations, Addis Ababa University. Zelalem Muchie, Graduate Student, Department of Political Science and International Relations, Addis Ababa University. 


\section{Introduction}

Horn of Africa is the single most geo-strategically important region of the world. Its geostrategic significance is related with the Red Sea, oil and "the Nile factor" (Mesfin, 2004). The region is significant for international trade (import and export), maritime security, anti-piracy operation and anti-terrorism campaign, access to the world's largest oil in the Middle Eastern Arab Gulf (Amare, 1998; Mesfin, 2004). This makes the region historically "an athletic field" of foreign powers. Historically, the region had been "a playing field" of Ottoman Turkey, Portugal and Egypt (Belete, 2006), during colonial period between and among Britain, Italy and France (Reece, 1954), during cold war between US and Soviet Union (Makinda, 1982; Schwab, 1978; Kimani, 1993), and now between Arab countries, Western and the emerging powers of the "Rest" notably China and India.

In the 21st century, Horn of Africa has become world's first ever-largest military base of foreign powers. It can be argued that the region has become "a military garrison": US, France, Germany, Italy, Japan, China and Saudi Arabia have already established their military base at Djibouti and Russia will join very soon while Djiboutian rejected Iranian request (Sun \& Zoubir, 2016). The militarization of the Horn is both an opportunity as well as a risk for Ethiopia, a nucleus and landlocked country of Horn of Africa. This paper, therefore, analyze the opportunity and security implication of the advent of competing foreign powers in the geostrategic Horn of Africa for Ethiopia. Accordingly, the paper argues that since the advent of foreign powers in Horn of Africa is both an opportunity and risk for Ethiopia, there is a need for a rational and responsive domestic and foreign policy aimed at utilizing the opportunity, minimizing the risk and countering neo-colonialism and "Clientelism".

Methodologically, the study employs qualitative research methodology. Accordingly, the study used secondary source of data; collected from books, published journal articles, published and unpublished thesis, governmental and non-governmental organization reports and remarks, and other internet sources. Given the data gathered are qualitative; the study employ qualitative data analysis techniques.

\section{Horn of Africa: Analysis of Its Geostrategic Significance}

The Horn of Africa is highly unstable and conflict-prone region because of endogenous and exogenous factors (Alem, 2007; Mesfin, 2004). As far as Horn of Africa concerned, there is no consensus about what constitute Horn of Africa. Some scholars tended to incorporate Uganda while others exclude Sudan, South Sudan and Kenya. The criterion to categorize countries as part of Horn of Africa was first developed by Professor Mesfin Wolde-Mariam ${ }^{1}$. According to him, Horn of Africa contains Ethiopia, Eritrea, Djibouti, Somalia, Kenya, Sudan, and South Sudan (Mesfin, 2004). Therefore, for the purpose of this paper, Horn of Africa refers to the area encompassing Ethiopia, Eritrea, Djibouti, Somalia, Kenya, Sudan, South Sudan, Somaliland and Punt land. Among these only Ethiopia and South Sudan are landlocked while others are littoral States of the Red Sea. Thus, physiographically Ethiopia is located at the centre and heart of the Horn of Africa.

\footnotetext{
${ }^{1}$ First, all countries having a physical border with Ethiopia are part of Horn of Africa. Ethiopia is the only country in the Horn of Africa that has a physical boundary with all of the Horn of African countries. Thus, Ethiopia is the nucellus in the Horn of Africa. Second, countries that have border only with Horn of African countries are purely part of Horn of Africa. Therefore, Ethiopia, Eritrea, Djibouti and Somalia have border only with Horn countries and thus they are entirely part of Horn of Africa. Third, countries which have border with both the Horn of African countries and others are half or partial Horn countries. These countries are Kenya and the two Sudan (Mesfin, 2004).
} 
First, all countries having a physical border with Ethiopia are part of Horn of Africa. Ethiopia is the only country in the Horn of Africa that has a physical boundary with all of the Horn of African countries. Thus, Ethiopia is the nucellus in the Horn of Africa. Second, countries that have border only with Horn of African countries are purely part of Horn of Africa. Therefore, Ethiopia, Eritrea, Djibouti and Somalia have border only with Horn countries and thus they are entirely part of Horn of Africa. Third, countries which have border with both the Horn of African countries and others are half or partial Horn countries. These countries are Kenya and the two Sudan (Mesfin, 20 04).

Horn of Africa is geo-strategically significant because of Red Sea, oil and Blue Nile. First, the Red Sea is the main line of communication which connects Europe and Asia. Al-Yadoomi (1991) depicts this fact as "the Red Sea is a part of the shortest and fastest waterway between the East and the West with considerable geopolitical advantages" (p. 1). So, the question is what makes Horn of Africa geostrategic important? First, it is its proximity to the Red Sea that makes important. Except Ethiopia and Sudan, all Horn of Africa countries are "littoral states" of the Red Sea. Thus, the Horn of Africa is a bridge between Africa and the Middle East, oil endowed region (Dias, 2013). Second, its proximity to Strait Bab el Mandeb has made the region an important geo-strategic. The Bab el-Mandeb Strait is located at the farthest southwest point of the Arabian Peninsula and the coast of Horn of Africa. According to Al-Yadoomi (1991), the Arabia Peninsula and Horn of Africa are separated by a distance of only 22 miles. This makes the strait the shortest and bottleneck of the Red Sea gateway.

Bab el-Mandeb Strait is belongs to four countries of which three are Horn countries, Djibouti, Eritrea and Somalia (Ibid). Al-Rahman (2013) stated that “... the region is the gateway from and to the Red Sea, Aden Gulf, Arab Gulf and the Indian Ocean it attracts the interest of local, regional and international powers that seek control and domination over the region" (p. 55). This makes the Horn always been a focus of interest for different powers.

Third, what makes Horn a geostrategic is its proximity to the Gulf oil. Industrialized nations, both the Western and emerging south powers, are highly dependent on Gulf and Africa oil. Arab countries economy is also dependent on oil "which constitutes in some countries 93\%-100\% of their total exports" (Al-Yadoomi, 1991, p. 12). In all cases Gulf oil passes through the Bab al-Mandeb Strait. As a result Western and emerging South powers wants to ensure an uninterrupted flow of oil to their respective regions. In contrast, Arab countries strategy is to make the Red Sea an Arab lake. This makes the Horn geo-strategically significant for foreign powers.

Finally, the region has paramount importance for maritime security, naval base, military base, anti- piracy and terrorism. Pirate attacks around the coast of Somalia and the Gulf of Aden has become the concern of the shipping industry (Onuoha, 2010). Thus, the area is important for counter piracy operation. Alem (2007) describes overall significance of Horn as follows:

The geopolitical importance of the Horn of Africa deriving from the region's location at the crossroads of trade flows, cultural links and military strategic interests for nations of the world has turned it into a major theatre where governments, movements and political groups large and small have sought to intervene in the internal affairs of the area. (p. 15)

All this made the region geo-strategically important. Thus, foreign powers eagerly involved in the region to control the Red Sea coastal area. 
Second, though the geo-strategic importance of the Horn outweigh its economic significance, economically the region is not irrelevant. Rather there are economic possibilities to be considered. The region is important for mineral exploitation, especially oil and gas (Woodward, 2005). Oil is found in South Sudan and Ogaden, Ethiopia. Thus, resource particularly oil is another reason.

Finally, another contentious issue in pre-colonial, colonial and post-colonial period of the Horn politics is related with the egoistic and savagery intent to control the source of Blue Nile, Abbay. Ethiopia, a nucellus in the Horn region, is the source of Blue Nile which contributes $86 \%$ of the total flow of Nile. Though $86 \%$ of Nile river annual flows originated in Ethiopia, Egyptian life is in (directly) dependent on Nile (Erlich, 2002). Thus, Nile is Egyptian fact of life as "there would be no life in Egypt without Nile". It is this undeniable fact that pushed Egypt and its protectorate of the late 19th and 20th century, Britain, to control the source and surrounding area of Nile. Both countries had been used different strategies and tactics, diplomacy and military, found cost-effective in controlling Nile. Beside this, other countries notably pro-Egypt and its Arab allies has been involved in the hydro-politics of Nile with the aim of protecting Egypt's national interest. Thus, as far as Nile is concerned, it will continue to be the subject of power politics. No doubt that Nile contributes another geo-economical, geo-political and geo-strategic significance of the Horn of Africa ${ }^{2}$. The 1891 Anglo-Italian protocol which was signed between Britain (representing Egypt and Sudan) and Italy (representing Eritrea) was a diplomatic strategy to control the water of the Nile. The 1902 agreement between Emperor Menelik II of Ethiopia and Britain on the behalf of its colonies also intended to the benefit of Egypt by downgrading the interest and very right of Ethiopia. The 1906 Tripartite treaty signed by the three colonial powers also manifested to partition Ethiopia and to control the source of Blue Nile, Abbay. The 1925 Anglo-Italian agreement also not different from other treaties signed between colonial powers. The 1929 Anglo-Egyptian Agreement was also aimed at securing Egypt's interest. The 1959 agreement between Sudan and Egypt also aimed at securing the interest of the signatory countries (Ademnur, 2003).

Generally, Ethiopia lies at the heart of world's most geo-strategically important region. The region is unstable that has inter-state, intra-state and ethnic conflicts, terrorism and fundamentalism. It is the uninterrupted involvement of foreign powers in the region that have changed the already instability of the region from bad to worse. This has made the region the military barracks of the super powers that threatens the security of the region. The following section depicts securitization of the region in light of foreign powers involvement and their interests.

\section{Horn of Africa: A Playing Field of Foreign Powers}

Horn of Africa has been the "athletic field" of foreign powers. Its geographical location attracts international and regional powers. Horn of Africa in particular Djibouti is the only region in the world in which US, French, Germany, Italy, Spanish, Japanese and recently the Chinese military forces are stationed simultaneously (Sun \& Yahia, 2016). This is largely due to the regions strategic location. First, the Red Sea is

\footnotetext{
2 The 1891 Anglo-Italian protocol which was signed between Britain (representing Egypt and Sudan) and Italy (representing Eritrea) was a diplomatic strategy to control the water of the Nile. The 1902 agreement between Emperor Menelik II of Ethiopia and Britain on the behalf of its colonies also intended to the benefit of Egypt by downgrading the interest and very right of Ethiopia. The 1906 Tripartite treaty signed by the three colonial powers also manifested to partition Ethiopia and to control the source of Blue Nile, Abbay. The 1925 Anglo-Italian agreement also not different from other treaties signed between colonial powers. The 1929 Anglo-Egyptian Agreement was also aimed at securing Egypt's interest. The 1959 agreement between Sudan and Egypt also aimed at securing the interest of the signatory countries (Ademnur, 2003).
} 
the main transit of oil ships both in the Mediterranean and Indian Ocean. Moreover, the Red Sea, Gulf of Aden and Indian Ocean are the main shipping route for goods from the Middle East and the Far East to Europe and the Americas (Abera, 2013). It is also a main transit of oil producing Arab countries oil ship into East, China, Japan, India, Europe, and America. Thus, it can be argued that international and regional powers have an undeniable interest in controlling the area.

Second, the Arab world have age-old dream to establish Arabic and Islamic based Strong and rich Arab union though suspicion of each other remains a challenge. Because of the unbalanced interest and rivalry between the Arab and the non-Arab countries over the area, the region becomes the playing field of both regional and international powers. Third, the everlasting Arab-Israel conflict increases the geo-military significance of the region. Israel also wants to save the Red Sea from becoming an "Arab Lake" (Al-Yadoomi, 1991; Woodward, 2005). Thus, Israel's singular alternative is to strengthen its relation with non-Arab country of the region, mostly Ethiopia. But, Ethiopia's tendency to Israel undoubtedly may affect its relation with the Arab world since it is encircled by Arabs. Fourth, the region's geo-strategy for maritime security and anti-piracy increased the significance of the region. The summation of these reasons makes Djibouti to be the military fort of foreign powers.

\section{The West and the Horn of Africa}

The Western has uncompromised interest in the region: economic, political, security and military (Al-Yadoomi, 1991). Among the West, French and American have largest military presences in the region. In the words of Woodward (2005) "Horn appeared on the agenda in the White House mainly for geo-strategic reasons" (p. 3). It can be argued that US presence in the Horn of Africa has been a spin-off of America's interest to maintain its unchallenged post-cold war hegemony. This meant that US foreign policy towards Horn of Africa driven and largely determined by its national interest (Samatar, 2007). The "war on terror" in the aftermath of 9/11 terrorist attack, the intention to control the Red sea coastal area and Persian Gulf oil, to save its Middle East ally, Israel and to sustain its superiority- can be leveled as the determinant of US increasing involvement in the Horn politics.

To meet those interests, US established, US established its first military base in Horn of Africa, Djibouti. In 2002, US established the Combined Joint Task Force-Horn of Africa (CJTF-HOA) at a former French Foreign Legion post in Djibouti. In 2008 CJTF-HOA was integrated into the newly created US Africa Command (AFRI-COM) (Styan, 2013; Jamieson, 2009). The stated mission of US permanent military base in Djibouti is to collect intelligence, strengthened the regions internal security capabilities and civic programmes, and to disrupt and defeat international terrorist groups posing threat to the United States, it allies and their interests in the region (Nicoll, 2007; Styan, 2013).

However, the US presence in the region is far from the officially confirmed altruistic reason. First, the US military deployment in Djibouti, most geo-strategic Horn country, has shifted from a soft military presence to a large garrison. Why this shift occurred? Second the US in the aftermath of cold war has been closing a number of military bases in Europe and East Asia, but US started establishing a new military garrison in Horn. So, why the United States established its military presence in Djibouti? Thus, it falls under US national interest in the region. US military presence in the Horn is multifarious: Geopolitical, geo-economic and security.

First, one of US strategic interest is ensuring US energy security by protecting access to oil and gas reserves. Thus, due to its proximity to the source of Middle Eastern oil in the Gulf and even Africans oil 
endowed regions, the Horn found cost-effective for US in protecting oil source by military facilities and bases in the region (Styan, 2013; Jamieson, 2009).

Second, US military base in the Horn is part of the strategy of the so-called "global War on Terror". The spread of Islamic extremism in the region is a threat to US and its regional allies because terrorist groups may control oil areas and thus maritime security and oil fields might be at risk. In this regard, the region is vulnerable for terrorism since the region is close to Middle East and Arab. Moreover, Sudan, Somalia and Yemen are either the home for Al-shabab-Al-Qaeda affiliated group or supporter of terrorist groups (Nicoll, 2007). Thus, US military presence in the Horn of Africa, Djibouti, is to neutralize terrorist groups from Somalia, Sudan, and Yemen.

Third, US another interest in the region is to protect its Middle East important ally, Israel. Seven of the nine states that line the Red Sea identify themselves with the Arab-Islamic world (Kimani, 1993). Thus, preventing the Red Sea from becoming an "Arab lake" is another issue. One of age-old Arabs dream is creating a strong Arab and Islam based unity. This has long-term effect on the very existence of the State of Israel and even Ethiopia-both of which are non-Arab and Islam countries of the region. Thus, using tactics of countering the establishment of a strong and rich Arab union is in the interest of US.

The other Western country which has military presence and uncompromised interest in the Horn is France. France's interest in the Horn can be traced back to 1939 (Liebl, 2008). France remains a dominant power in Djibouti even after an independent Djibouti was established in 1977 (Styan, 2013). Not surprisingly, France has growing military presence in the country. France has economic and security interest in the region. Liebl (2008) describe the significance of French military base as follows:

... French presence not only ensures that France has a secure military platform to maintain its position in East Africa, the Middle East, and the Indian Ocean, but more importantly enables France to monitor the safety and security of maritime traffic (both military and commercial) through the Babel Mandeb into the Red Sea. (p. 3)

However, the increasing involvement of US and China endangers France's interest. Liebl (2008) argued that "any loss of French presence in Djibouti directly threatens the French lifeline to its Indian Ocean- and Pacific Ocean-based citizens and dependents, numbering over 1.4 million people". Thus, the region is the subject of "Big powers" competition.

Beside the two Western countries, others such as Germany, Italy and the whole Europe through European Union (EU) have an interest in the region. For instance, EU has been involved in the region mainly in countering piracy operation (Council of the European Union, 2011). Thus, the Horn of Africa goes beyond foreign States competition and it successfully attracts supranational institutions. This has its own repercussion to the regions States particularly Ethiopia, landlocked State of the region.

\section{The "Rise of the Rest" and the Horn of Africa}

It is not only the westerns who have interest in the Horn, but the emerging powers of the South too. Both the Arab and non-Arab countries such as Egypt, Saudi Arabia, Qatar, Iran, Turkey, Israel, Japan, China and India all have involved in the Horn to safeguard their interest.

Despite the China binary foreign policy principle, non-interference and non-intervention, recently China shows an interest in Africa particularly in the Horn politics. At one time China becomes the patron of Sudan (Assogbavi, 2010). China also participated in peacekeeping mission of the region. It has also built its first overseas military base in Djibouti (Braude \& Jiang, 2016). Moreover, China has been increasingly involved in 
various sectors of Ethiopia.

Thus, China has an eminent involvement in the Horn politics than any other foreign powers. Some scholars tend to view the Chinese increasing involvement in the Horn of Africa as opportunity, a counterweight to America and the West. However, others stated that China is not different from the West. Rather, Chinese greater involvement in Horn of Africa may be neo-colonial in consequence. Thus, the "rise of China" in the Horn of Africa is in question.

Saudi Arabia also has military presence in Horn, Djibouti. Saudi military presence in the region is intended both as a defensive and a potential offensive measure in its pan-regional conflict with Iran (Braude \& Jiang, 2016).

Thus, Horn of Africa has become the "springboard" of foreign powers. Foreign powers involvement in region has economic, political and security implication for countries of the region particularly Ethiopia, the heart of and landlocked country of the region. The region is very fragile and volatile in which conflict and war may take the form of interstate, intrastate, ethnic, and war by proxies. Scholars subscribe to the view that the regions instability is largely due to external players (Alem, 2007). Thus, Ethiopia is a country in between regional dynamics and external players. The next section analyses the opportunity and implication of foreign power involvement for Ethiopia.

\section{The Rise of Foreign powers in the Horn: An Opportunity for Ethiopia?}

France, US, Japan, Saudi Arabia, Italy, Spanish, Germany and China have already establishing military bases in Djibouti, Ethiopia's neighbor (Sun \& Zoubir, 2016). Besides this, Iran also requested Djiboutian officials to establish a military base. However, Djibouti officials do not allow it and Russia also will come very soon. So, what does this mean to Ethiopia? The presence of foreign powers in Horn has security, military, economic and political contexts for Ethiopia. Thus, Ethiopia needs to work hard and faster to expand its influence in the area.

First, the increasing military presence in Djibouti may be seen as an opportunity in the field of military: exchange of intelligence, training, technology transfer and skill. However, this requires very skilful diplomacy. For instance, the work of CJTF-HOA is to prevent conflict, promote regional stability, protect coalition interests and prevail against extremism in region through diplomacy, development and defence (Berrigan, 2007). This requires working with strategically important country like Ethiopia. Berriang (2007) stated that members of the Ethiopian armed forces have been on "fishing trips" with the US military. CJTF-HOA also gives training to intelligence and communications personnel from the Ethiopian National Defence Force (ENDF) and Djiboutian Armed Forces (FAD) and they also visited the Combined Joint Task Force-Horn of Africa with the aim of working with US intelligence and communication specialists (CJTF-HOA, 2015). US and Ethiopia also recently signed a new agreement on March 2016 to enhance security partnership (CJT-HOA, 2016). However, the question is whether the military cooperation of US with Ethiopia possibly gives a "fish to eat for a day or teach them how to fish and they will eat forever". This requires diplomatic persuasion on the part of Ethiopia. Beyond this, US also increased its arms sale and military aid for Ethiopia. Thus, on the part of Ethiopia, its foreign affairs personnel's must draw lesson from the country's previous leader's success story so as to achieve the country's interest.

Second, foreign power military base in the region would strengthened the country's increasing role towards maintaining regional security. Ethiopia would not secure unless the Horn is secured. Any security risk 
of the region has (in) direct security threat (Mesfin, 2004). It is this reason that pushed Ethiopia to work towards regional peace by fighting terrorism. As far as security is the concern of all foreign powers that have military base in Djibouti, they like or not, maintaining the region's secure is mandatory. In this regard, it is only Ethiopia who has largest military power in the region. Thus, working with Ethiopia, hegemony of the region, in security area could found cost-effective for all powers. Again this requires a skilful diplomatic effort on the part of Ethiopia.

Third, the recent commencement of China military base in Djibouti has economic worth for Ethiopia. China started building its first overseas military base this year. Beyond this, China is also building other economically significant infrastructure: international airport, a water supply project, railway line linking Addis Ababa to Djibouti's new port, and a gas project terminal which allowed Ethiopia to export gas to China via a pipeline from Ethiopia to Djibouti (Jeffrey, 2016; Tao, 2016; Igbinoba, 2016). Regarding the railway project, Getachew Betru, chief executive of the Ethiopian Railway Corporation (ERC), in an interview with Harper, said that World Bank and European Union were unwilling to fund the project (Harper, 2015). He further stated his hope on china as "we ended up with the Chinese, who are not only constructing the railway, but providing most of the funding too" (Harper, 2015). The project will allow Ethiopia a link to the sea and Djibouti access to the country's emerging market of 95 million people. Surprisingly, Ethiopia also planned a railway project connecting Horn countries which will extend from the Red Sea in Djibouti all the way across Africa to the Atlantic Ocean. To achieve its dream of connecting the sub region, Ethiopia needs China. Reciprocally, China needs Ethiopia because of Ethiopia's place in Africa.

From another perspective, China has been investing in East Africa particularly in Ethiopia, an Island of stability. Thus, China for its own sake will cooperate with Ethiopia in different fields. However, Ethiopia must continue its relation with all foreign and regional powers in the area. Thus, drawing lesson from the Derg's foreign policy failure has worth significance.

Fourth, it can accelerate regional integration in particular the intended unification of the Ethiopia and Djibouti. Recently Ethio-Djibouti relation has been increased and becoming a model of other Africans. Djiboutian president Ismail Omar Guelle, in an interview with Journalist, said that there was no difference between them: "We believe that Ethiopia is Djibouti and Djibouti is Ethiopia, no difference at all" (Aderibigbe, 2015). He added that "if it is the wish of the Ethiopian and Djiboutian peoples, we have to translate the unification into action" (Ghelawdewos, 2014). Ethiopia also reciprocates it by building a new railway connecting Addis Ababa and Djibouti and an agreement also signed between them about free water supply. As The Economists reported, Ambassador Dina Mufti stated that the agreement which give-up land in Ethiopia's Somali region to Djibouti for water excavation is part of the process of political unification (The Economist, 2014).

In this regard, a single-most accelerating factor of integration is infrastructure like railway, road, electrification and trade linkage. According to Urgessa (2014), common infrastructure is ,prime pillars of integration" (p. 9). He Stated that "the successes of such common infrastructure depend on the availability of aids and loans from funding countries like China" (Ibid). In this context, infrastructure massfication has been doing by China (Igbinoba, 2016). So, China for its own sake may support the "Horn Africa's dream of integration". However, there is a challenge which comes from the Western and Arab world both of which never want strong united Horn of Africa. The West may strategically slow-down the integration process by using 
their "carrot-stick" policy. In this regard, Ethiopia must do its homework. Ethiopia should use the vacuum arise as a result of the current upheaval "Arab uprising".

In general, the advent of foreign powers in the Horn might have both opportunity and risk. Using the opportunity for the best interest of Ethiopia requires skilful diplomat, designed tactics and strategies. Nevertheless, the securitization of the Horn has its own security implication for Ethiopia, a landlocked and "island of stability" in the region. The next section examines the security dilemma of the region with a particular reference to Ethiopia.

\section{Security Implication for Ethiopia}

The militarization of Horn of Africa due to foreign powers involvement has security implication for Ethiopia, encircled State by self-interested foreign power. However, it seems difficult to understand the security issues of the region. The commencement of too-many military base and the volatile nature of the region make the security issues a "security dilemma". Ethiopia has been existed long, in times influencing and affecting and at times influenced and affected, in this security dilemma region. The security risk of foreign powers advent in the Horn is multifarious: threatening territorial integrity of the State (national security), endangering national economic security, national military security and national political security (Solomon, 2016).

First, the militarization of the Horn of Africa may pose a threat to the national security of Ethiopia. Foreign military presence alone might not threaten the national integrity and sovereignty of Ethiopia. Rather territorial integrity of Ethiopia can be threatened by a combination of different factors: the country' $s$ internal politics, the country's nature, extent and purpose of involvement in Horn politics itself; the Horn evil political culture of supporting ones neighboring insurgents, foreign countries sale and supply of arms to countries and even insurgents, terrorist groups, and the rivalry among the Arab, Western and the South emerging powers to control the Red Sea coastal area (Ulrichsen, 2011). First, the absence of constitutionalism, the existence of liberation front (Ogaden National Liberation Front and Oromo Liberation Front) and organized forces who are fighting to seize power such as the combined force of Patriotic-Ginbot 7-may pose a danger. Second, the evil political culture of Horn countries, supporting neighbors insurgent groups by providing all the necessary resources including access to land, arms and even personnel, may further aggravate the internal situations. In the Horn political history, no country can be found immune of supporting neighboring countries insurgent groups. Currently Eritrea, a destabilizing country of the region, is supporting Patriotic-Ginbot 7, which is identified as terrorist group by Ethiopian ruling government. The increasing interaction of Eritrea with Iran and Saudi Arabia may help it to gain military assistance including weapons and paradoxically Patriotic-Ginbot 7 force would have easy access to weapons. The recent opposition of Djiboutian officials of Iranian request to build military base in the region may push Iran to work hardly with Eritrea to control the Red Sea. Finally, the country's internal political weakness and Horn evil political culture may be conducive for foreign powers to play the game which may pose a national security threat. Thus, it can be argued that foreign powers military presence alone may not threaten Ethiopian territorial integrity unless it combined with internal and regional security dilemma. So, internally, constitutionalism and externally improving relation with neighbor countries particularly with Eritrea is not only imperative but the only option of survival. Ethiopia should also learn from Pakistan, US ally in its "war on terror" but later Pakistan has been safe haven of terrorist groups (Mesfin, 2004). Thus, there is a need to normalize its relation with Eritrea. 
Second, foreign powers presence in the region may threaten the national economic security of Ethiopia. Ethiopia is a landlocked country of the region. Its only access to the sea is through Djibouti. But, Djibouti has become a military garrison (Qureshi, 1979). Djibouti is under the pressure of foreign powers and in the near future Djibouti alone may not determine its own fate. This would be greatest threat of the very existence of both Ethiopia and Djibouti. Ethiopian entire reliance on the port of Djibouti and the increasing militarization of Djibouti may risk both countries national economic security. Thus, both countries should work together to counter the planned neo-colonization. As far as Djibouti is the only port of Ethiopia's import and export trade, Ethiopia should use all the available means to protect its economic interest and at the same time search alternative out way.

Third, the presence of military base in the region has a national political and military security risk (Haile, 2015). First, ideologically the existing foreign powers in the region have competing and conflictual political ideology: Chinese socialism, Western liberalism, Arab countries Arab and Islam based nationalism, Islamic fundamentalism, Israelis Zionism and so on. If ideology able to become a determinant factor to establish future relation, it will be only Horn of Africa which become an "ideological battle field". This has its own repercussion for Ethiopia. Thus, Ethiopia must learn from its past foreign policy failures during the cold war. Ethiopia should work not to replace cold war ideology based foreign relations.

In general, the advent of foreign powers in the Horn of Africa, "island of foreign strategic athletic field", has national security, economic, political and military risk for Ethiopia. Nevertheless, it is also an opportunity for Ethiopia. So, the question is "how Ethiopia is able to utilize the available opportunity without risking its national interest and security"? How Ethiopia possibly minimize the perceived security risks? What strategies, policy orientation, tactics and instrument Ethiopia will use to defeat the battle? The next section analyses policy options.

\section{In Search of a Rational and Responsive Foreign Policy}

Ethiopia found at the nucleus of Horn of Africa, a region becoming military garrison and an area to play a political drama. The over-increasing foreign powers involvement in the region is both an opportunity and risk for Ethiopia. Not surprisingly, other foreign powers may also join very soon mostly Russia, a friend of Egypt. Thus, a rational, responsive and reactive domestic and foreign policy is not only imperative for Ethiopia but it is also the only alternative of its survival. A rational and responsive policy means a policy that is consistent, reason based, national interest than ideology driven, timely responsive of the existing changes in the system, people centered than ruling party and group centered and context based.

First, the domestic policy setting should be revisited by drawing lesson from past failures and successes. In this regard, the regime neglected the single-most important detrimental factor of a country's survival which is constitutionalism. It is absence of good governance, constitutionalism and over militarism which calls the demise of Derg. Thus, domestically the government must adhere the constitution. Absence of constitutionalism may increase the country vulnerability to external interference through moral or material support (Mesfin 2004).

Second, in foreign policy setting, there is a need of taking consideration important aspects of policy options. First, the foreign policy setting of the country neglected past experiences. Previous Ethiopian leaders perceived Ethiopia as "a state of Island" encircled by enemy. But, the current regime perceived it as a country encircled by "peace countries". This seems a self-interested policy driven. We cannot deny the reality on the 
ground. With the exception of Kenya, Ethiopia fought a battle with all of its neighbors: Emperor Yohannes IV with Sudan, Derg with the Somalia republic, and the current regime with Eritrea. Moreover, with the exception of Kenya others are member of Arab League which aspire Arab unity. Age-old dream of Arabs is the creation of a strong, militant and prosperous Arabic union. If this is to be achieved, then Ethiopia would be encircled by Arabs of which some never want strong Ethiopia. So, assuming Ethiopian neighbors as "peace lover" is naive. Thus, Ethiopian foreign policy should be revisited by perceiving its neighbors as both "peace and war lovers".

Second, Ethiopia must continually strengthen its good relations with countries of the region. In this regard, improving its relation with Eritrea would be its homework. A tense relation with Eritrea would significantly affect its internal security. Beyond this it increases its vulnerability too. Thus, Ethiopia should use all the available resources to normalize its relation with Eritrea. For a long plan, Ethiopia also required to play a role in accelerating Horn of African integration. A strong Horn of African union is paramount for the region (Shinn, 2010; Mesfin, 2004).

Third, Ethiopia should strengthen its relation with all of those powers involved in the Horn of Africa. In this regard, a skilful diplomacy, strategy and tactics are required. Moreover, the country should avoid Derg's style of over-self-reliance on one external power. Rather it is worthwhile when necessary to replicate Menelik's foreign policy of "playing one foreign power over the other" (Belete, 2006). Moreover, emphasis also should be given to the importance of collective security.

Finally, the country as well as the region should work towards countering neo-colonialism and patron-Clientelism. The "rise of China" in Horn has been increased particularly in Ethiopia. We are not a "fortune-teller" but the already existed asymmetrical relation is foreshadowing "Clientelism". Such suspicion and danger has been officially notified by US president Barack Obama by saying "so many Africans have told me... We don't want patrons; we want partners who help us to build our own capacity to grow" (Obama's speech at AU, July 28, 2015). The "rise of china in Africa" in general also led scholars to warn African leaders to counter the danger of patron-client relationship between China and African countries. For instance, Hairong and Barry (2007), in their studies of the "China -in- Africa discourse", used the title "The Forest for the Trees" to illustrate reciprocity in Sino-African relations. Likewise, A New York Times editorial, as cited in (Zeleza, 2008, p. 175; Hairong \& Sautman, 2007, p. 9) used the title "Patron of African Misgovernment" to depict China-Africa relations. In this regard, the case of Ethiopia is not different from that of other African countries. Therefore, there is a need to have a strategic way of engagement aimed at countering the perceived patron-client relations between China and Ethiopia particularly between the two countries ruling party. Falling to adopt countering strategy may be quoted as officially acknowledging "Clientelism". Moreover, in the words of Fantu and Obi (2010), it would be also "neo-colonialism by invitation".

In general, Ethiopia must work its homework to use the opportunity by minimizing the risk. In this regard, past Ethiopian foreign policy failure and success has paramount importance. Therefore, both rational and responsive policy measures should be taken.

\section{Conclusions}

Attempt has been made to analyze the security implication and opportunity of the advent of foreign powers in Horn of Africa with particular reference to Ethiopia. Horn of Africa is the world single-most important geo-strategic region. Its geo-strategic significance is related with the Red Sea, oil and the Nile factor. Historically, the region had been an athletic field of foreign powers between Ottoman Turkey and Egypt, during 
colonial period between France, Britain and Italy, during cold war between US and Soviet Union, and now between different competing Arab countries, Western and the emerging South notably China. Now, Horn of Africa has become world's first ever-largest military base of foreign powers. It can be argued that the region has become "a military garrison": US, France, Germany, Italy, Spanish, China and Saudi Arabia have already established their military base at Djibouti and Russia will join very soon while Djiboutian rejected Iranian request. The militarization of the Horn is both an opportunity as well as a risk for Ethiopia, a nucleus and landlocked country of Horn of Africa.

It is an opportunity in areas of military, regional stability, accelerated factor of unification and economic worth. However, these opportunities are largely determined by the Ethiopia's diplomatic utmost effort and policy reorientation. Despite these opportunities, the rise of foreign powers in the Horn of Africa has a security risk: national security, economic, political and military. The overt-militarization of the region may threaten the national interest and security of Ethiopia.

Therefore, Ethiopia needs a rational and responsive domestic and foreign policy to utilize the opportunities and at times to minimize the security risk. First, domestically constitutionalism is highly needed which is imperative and also matter of survival. Second, regionally, Ethiopia must stabilize and normalize its relation with Eritrea. Falling to do so would mean officially allowing Eritrea to be a brigade for insurgents like Patriotic-Ginbot 7 and foreigners to attack Ethiopia at times necessary. Moreover, Ethiopia must strength its relation with all of its neighbors. In this regard, maintaining a good relation with Djibouti and at the same time searching another alternative of port is not only imperative but also the only path. Third, Ethiopia must maintain a good relation with foreign powers that already established a military base in Djibouti. In this regard, over-reliance on some foreign powers and neglecting others, becoming an instrument of foreign powers must be avoided. Rather Ethiopia must use a rational policy and at times must follow the foreign policy of Emperor Menelik "playing one foreign power over the other". Moreover, emphasis also should be given to the importance of collective security. Finally, Ethiopia and the region must work towards countering neo-colonialism and patron-client relations. Falling to adopt countering strategy may be quoted as officially acknowledging "Clientelism". It also would mean "neo-colonialism and Clientelism" by invitation.

\section{References}

Abera, S. (2013). Conflict patterns in the Horn of Africa in Post-Cold War periods. Unpublished Master's Thesis, Addis Ababa University, Addis Ababa, Ethiopia.

Ademnur, J. (2003). The question of the Nile in Ethio-Egyptian relations: Challenges and opportunities. Unpublished Master's Thesis, Addis Ababa University, Addis Ababa, Ethiopia.

Aderibigbe, N. (February 12, 2015). Its time Ethiopia and its neighbors took the bull by the horns. Ventures Africa. Retrieved June 21, 2016, from http://venturesafrica.com/its-time-ethiopia-and-its-neighbours-took-the-bull-by-the-horns/

Alem, H. (2007). Political violence, terrorism and US foreign policy in the Horn of Africa: Causes, effects, prospects. International Journal Of Ethiopian Studies, 3(1), 1-27.

al-Rahman, A. F. (2013). A change in the African Horn balance of powers. African Perspectives, 11(38), 55-57.

Al-Yadoomi, H. (1991). The strategic importance of the Bab Al-Mandab Strait. Published Project Paper. Carlisle Barracks, Pennsylvania: US Army War College.

Amare, T. (1998). Peace and stability in the Horn of Africa: Problems and prospects. Northeast African Studies, 11(1), 75-108.

Assogbavi, D. (2010). The role of China in peace and security in Africa. In S. Marks, A. Harneit-Sievers \& S. Naidu (Eds.), Chinese and African Perspectives on China in Africa. Kampala-Uganda: Pambazuka Press.

Belete, B. Y. (2006). Djibouti: Yetgegni'netachin Mesferiya. Oland Printing Press.

Berrigan, F. (September 18, 2007). The new military frontier: Africa. Institute for Policy Studies. Retrieved June 20, 2016, from 
http://www.ipsdc.org/the_new_military_frontier_africa/

Braude, J., \& Jiang, T. (2016). Djibouti is jumping. Foreign Policy Research Institute. Retrieved June 20, 2016, from http://www.fpri.org/article/2016/03/djibouti-is-jumping/

CJTF-HOA. (September 6, 2015). Ethiopian, Djiboutian militaries broaden communication, intelligence system skills at $\begin{array}{lllll}\text { CJTF-HOA. } & \text { Jetrieved } & \text { June } & \text { 2016, }\end{array}$ http://www.hoa.africom.mil/story/17070/ethiopian-djiboutian-militaries-broaden-communication-intelligence-system-skills-a t-cjtf-hoa

CJTF-HOA. (April 7, 2016). US Ethiopia sign new agreement, enhance security partnership. Retrieved June 20, 2016, from http://www.hoa.africom.mil/story/19722/u-s- Ethiopia-sign-new-agreement-enhance-security-partnership

Council of the European Union. (November 14, 2011). Council of the European Union Conclusions on the Horn of Africa, 3124th Foreign Affairs Council meeting, Brussels.

Dias, A. M. (2013). Introduction: Understanding conflict and processes of state formation, reconfiguration and disintegration in the Horn of Africa. In A. M. Dias (Ed.), State and societal challenges in the Horn of Africa: Conflict and processes of state formation, reconfiguration and disintegration (pp. 3-14). Lisbon: Center of African Studies, University Institute of Lisbon.

Erlich, H. (2002). The cross and the river: Ethiopia, Egypt, and the Nile. United States of America: Lynne Rienner Publishers, Inc.

Fantu, C., \& Obi, C. (Eds.) (2010). The rise of China and India in Africa: Challenges, opportunities and critical interventions. Uppsala, Sweden: Zed Books Ltd.

Ghelawdewos, A. (December 18, 2014). The Unification of Ethiopia and Djibouti will be of Paramount Historical Significance. Tigrai Online. Retrieved June 20, 2016, from http://www.tigraionline.com/articles/ethiopia-djibouti-unity.html

Haile, T. (December 29, 2015). On Eritrea, Lesson for Ethiopia from Russia-Ukraine relations. Horn Affairs. Retrieved June 22, 2016, from http://hornaffairs.com/en/2015/12/29/ethiopia-eritrea-threats-lesson-russia-ukraine/

Hairong, Y., \& Sautman, B. (2007). The forest for the trees: Trade, Investment and the China-in-Africa Discourse. Hong Kong University of Science and Technology.

Harper, M. (November 23, 2015). Can Ethiopia's railway bring peace to Somalia? BBC World Service News. Retrieved June 20, 2016, from http://www.bbc.com/news/world-africa-34871074

Igbinoba, E. (2016). Economic implication of China's military base in Djibouti. Centre for Chinese Studies Commentary.

Jamieson, D. G. (2009) AFRICOM: A threat or an opportunity for African security? South African Journal of International Affairs, 16(3), 311-329.

Jeffrey, J. (April 6, 2016). Djibouti profits as superpowers make strategic inroads. The Irish Times. Retrieved June 20, 2016, from http://www.irishtimes.com/news/world/africa/djibouti-profits-as-superpowers-make-strategic-inroads-1.2599351

Kimani, J. (1993). Strategy for the Horn of Africa. Study Project. Carlisle Barracks, Pennsylvania: US Army War College.

Liebl, V. (2008). Military policy options to revise the French military presence in the Horn of Africa. Comparative Strategy, 27(1), 79-87.

Makinda, S. M. (1982). Conflict and the superpowers in the Horn of Africa. Third World Quarterly, 4(1), 93-103.

Mesfin, W. M. (2004). Adega Yan'zhabebebet Ye'Afrika Qend. Ethiopia: Addis Ababa.

Nicoll, A. (2007). AFRICOM: The United States' new combatant command. Strategic Comments, 13(2), 1-2.

Obama's speech at AU. (July 28, 2015). Remarks of President Barack Obama to the People of Africa at the African Union Headquarters in Addis Ababa, Ethiopia Tuesday, July 28, 2015. Retrieved August 03, 2015, from http://agenda2063.au.int/en/news/remarks-president-barack-obama-address-people-africa-au-hq-addis-ababa-ethiopia-tuesda y-july-28

Onuoha, F. C. (2010). Piracy and maritime security off the Horn of Africa: Connections, causes, and concerns. African Security, $3(4), 191-215$.

Qureshi, Y. (1979). Recent developments in the Red Sea Region with special reference to the Horn of Africa. Pakistan Horizon, $32(1 / 2), 142-159$.

Reece, G. (1954). The Horn of Africa. International Affairs, 30(4), 440-449.

Samatar, A. I. (2007). Continuity in US foreign policy in Africa: Antithesis of freedom \& democracy. Review of African Political Economy, 34(114), 714-717.

Schwab, P. (1978). Cold war on the Horn of Africa. African Affairs, 77(306), 6-20.

Shinn, D. H. (April 9, 2010). A vision for the Horn of Africa. Remarks at a Conference Hosted by Advocacy for Ethiopia and the Ethiopian National Priorities Consultative Process. Elliott School of International Affairs, George Washington University, 
Virginia: US.

Solomon, D. (2016). East Africa: Recent activities in the Horn, their implications for Ethiopia's national security. The Ethiopian

Herald. $\quad$ Retrieved June $24, \quad$ from http://www.ethpress.gov.et/herald/index.php/editorial-view-point/item/3513-recent-activities-in-the-horn-their-implications-f or-ethiopia-s-national-security

Styan, D. (2013). Djibouti: Changing Influence in the horn's strategic hub. Chatham House.

Sun, D. G., \& Zoubir, Y. H. (2016), The Eagle's nest in the Horn of Africa: US military strategic deployment in Djibouti. Africa Spectrum, 51(1), 111-124.

Tao, Z. (March 17, 2016). China's logistic hub in Djibouti to stabilize region, protect interests. Global Times. Retrieved June 21, 2016, from http://english.chinamil.com.cn/news-channels/pla-daily-commentary/2016-03/17/content_6964486.htm

The Economist. (July 14, 2014). Plans for deeper Djibouti-Ethiopia integration. The Economist. Retrieved June 20, 2016, from http://country.eiu.com/article.aspx articleid=702013454\&Country=Djibouti\&topic=Politics\&subtopic=Forecast\&subsubtopi $\mathrm{c}=$ International+relations\&u=1\&pid=184211002\&oid=184211002\&uid=1

Ulrichsen, K. C. (2011). The geopolitics of insecurity in the Horn of Africa and the Arabian Peninsula. Middle East Policy Council, 18(2), 120-135.

Urgessa, D. G. (2014). The Ethio-Djibouti Relations: Implications for sub-regional integration schemes in the Horn of Africa. Unpublished Master's Thesis, Addis Ababa University, Addis Ababa, Ethiopia.

Woodward, P. (2006). Us foreign policy and the Horn of Africa. Britain: Ashgate Publishing Company.

Zeleza, P. T. (2008). Dancing with the dragon Africa's courtship with China. The Global South, 2(2), 171-187. 